\title{
SUSTAINING INNOVATIVE INFORMAL EDUCATION THROUGH INTELLECTUAL PROPERTY
}

\author{
${ }^{1}$ Ratnaria Wahid, ${ }^{2}$ Norafidah Ismail, ${ }^{3}$ Bakri Mat \& \\ ${ }^{4}$ Khaliza Saidin \\ ${ }^{1,2,3}$ School of International Studies, Universiti Utara Malaysia \\ ${ }^{4}$ School of Education, Universiti Utara Malaysia \\ 1Corresponding author: ratnaria@uum.edu.my
}

Received: 11/6/2019 Revised: 18/8/2019 Accepted: 28/8/2019 Published: 31/7/2019

\begin{abstract}
Various technological innovations in ICT have brought about profound changes in major aspects of education, namely the content delivery or pedagogy, and the structure or management of both formal and informal education. Current technology has also offered the ease of copying or reusing new innovation without the need to acknowledge or compensate the creators. New books, and methods or techniques can easily be copied and digital resources may speedily be scanned and forwarded without much regard to the creators' effort or investment. These actions would potentially discourage creations of new innovations that would be useful for public lifelong learning. Understanding cultural perspectives in the relationship between the intellectual property system and religious works is significant since it analyzes the intersection of belief and culture with the application of the law. This paper explored the development of creativity and innovation in an informal education setting, specifically looking at Quranic teaching offered by private enterprises in Malaysia as a case study. This paper examined (a) to what extent the Quranic teaching and learning have been innovatively developed and (b) to what extent developers of new innovation in Quranic teaching and learning deem it necessary to protect their creations under intellectual property rights protection. This study utilized qualitative research, by way of document analysis gathered from reports, brochures, journal articles, newspapers, the Internet, websites and mass media focusing on the creativity and innovation in informal religious education. It also conducted
\end{abstract}


semi-structured interviews with several companies that used new innovative methods in teaching the Quran. The findings revealed that although intellectual property protection is seen as a valuable business asset which provides legal recognition and acts as quality control, intellectual property protection plays a minimal role in encouraging innovation or the spread of Quranic teaching.

Keywords: Intellectual property, Islam, Diversity, Public interest, Innovation.

\section{INTRODUCTION}

Intellectual Property protection is fast becoming a key aspect in sustaining innovative informal education in the age of the Industrial Revolution 4.0. Recent developments of data and digital technology have led to expectations that people change how they live, work, communicate, teach, learn or do business. Specifically, the IR 4.0 requires one to think creatively and necessitate major educational transformation in terms of its content, delivery, pedagogy and structure of delivering education across disciplines albeit in formal or informal education. These intellectual creations, inventions, literary works, designs, images and others may be protected by the intellectual property system in the form of copyright, trademark, patent or industrial design.

Like any other property rights, intellectual property rights allow creators or owners of protected works to benefit from their work or investment in a creation. This means that owners have the right to be compensated and attributed for the exploitation of their works. Such rights are clearly enumerated in Article 27 of the Universal Declaration of Human Rights, which provides the right to benefit from the protection of moral and material interests resulting from the authorship of scientific, literary and artistic productions. Intellectual property right is also recognized by the Paris Convention for the Protection of Industrial Property (1883), the Berne Convention for the Protection of Literary and Artistic Works (1886) and the TradeRelated Intellectual Property Agreements which are administered under the World Intellectual Property Organization (WIPO) and the World Trade Organizations. These international treaties are 
used as guidelines for all WTO member countries in administering intellectual property laws in domestic situations.

Despite widespread application of intellectual property law across jurisdiction, there has been much division between legal scholars on the subject of intellectual property protection and the need of public interests. The public may want easy access to useful works that may benefit community while private owners may require protection of their work from control and exploitation. In addition, what is considered as public interest is also debatable depending on the cultural and religious backgrounds. For instance, different from the Western culture, Muslim and Chinese culture tend to prioritize the society's interest much more, compared to individual property rights (Guanhong, 2004).

A much-debated question is whether intellectual property protection fares above the right to research, education and lifelong learning which is of public interest. This paper sought to examine the changing nature of teaching and learning in an informal educational setting due to the development of new innovation and creativity. A specific look at the teaching of the Quran was taken as a case study as it is one of the oldest and largest informal learning activities conducted around the globe. The aim of the study was to discuss some of the current innovations developed and applied in the context of Quranic teaching. The paper further aimed to understand the views and experience of creators and developers that might potentially carry different values on the importance of intellectual property in protecting their works and innovations.

\section{LITERATURE REVIEW}

\section{Intellectual Property and Public Interest Debates}

Proponents of intellectual property law argued that the intellectual property system could act as an incentive to innovate and further lead to commercial gain. Intellectual property protection is considered as a widespread popular factor that encourages the creation of more creative works and innovations (Burkitt, 2001) and helps increase access and enhances the enjoyment of culture and knowledge (Wipo, n.d.). Studies claimed that contributors to the creation of 
knowledge will be less inclined to continue creating knowledge when they have insufficient rewards or benefits and when others do not contribute equally but merely free-ride on their productions or innovations (Chou \& Passerini, 2009)

There are, however, increasing concerns raised by opponents of intellectual property protection that intellectual property may negatively hamper access to beneficial works. Previous research has established that intellectual property protection could stifle the dissemination of works, increase the market price and sometimes, to the extent of creating a monopolistic environment (Hilty, 2005; Shanmugaiah, 2012). With intellectual property protection, latecomer firms would need to face more challenges, especially if they have limited financial and human resources (Mets \& Kelli, 2014). Opponents of intellectual property rights protection claim that it only offers temporary monopolistic profits and leads towards privatizing goods rather than acting for the benefit of public good (Chou \& Passerini, 2009).

The World Intellectual Property Organization (WIPO) clearly aims for an efficient, and accessible intellectual property system that provides benefits to all. So far, however, there has been little discussion about intellectual property implementation in enterprises, small businesses and organizations by individually considering the differences in places, situations and subject matter. Moreover, looking at intellectual property from a different perspective, away from the common Western perspectives, deserves more attention. This concern can be evident in the WIPO Journal inaugural issue which views that it is premature to assume that other countries will always want the existing international intellectual property system since they may want something different. Yu (2012) also discussed the distinct values of Asian countries that might potentially lead to alternative paths or the reshaping of global intellectual property norms. Hence understanding different perspectives, beliefs, cultures and values deserve a much better scholarly attention.

\section{Intellectual Property Protection on Knowledge Assets}

In the increasingly knowledge-driven economy, knowledge is considered as a critical asset which needs to be protected. Examples 
of knowledge assets may include the brand name, image, process knowledge and even employee competence that may be treated as a critical asset to an organization (O'Donoghue \& Croasdell, 2009).

Intellectual property rights are now considered as the emerging currency of the knowledge-based economy. Intellectual property may be used as tools to assert ownership of knowledge assets which might be otherwise disseminated out of control (Carayannis \& Alexander, 1998). For instance, patents can be applied to business processes and software so that the knowledge underlying the processes may not be copied easily (O'Donoghue $\&$ Croasdel1, 2009). Failure to protect the knowledge asset may cause good inventions to be lost to competitors that may have a better position to commercialize the product or services at more affordable prices, leaving the original creator without any reward (Sukarmijan \& Sapong, 2014).

Knowledge, held by organizations, is now the primary source of innovation and market advantage. Different from other kinds of tangible properties, information and the codified knowledge owned, which are easily replicable, will not be diminished if they are used, copied or distributed to others. Yet, some companies view that the intellectual property of the knowledge asset should be fully exploited in order for the firm to operate efficiently (Carayannis \& Alexander, 1998). Sukarmijan \& Sapong (2014) emphasized the importance of cooperation between IP offices, SME support institutions and business associations and governments for better and more effective use of IP among SMEs.

Relatively, little research has been carried out on businesses or Small Medium Enterprises (SMEs) that create new innovative works for the purpose of providing informal training or education for the public. Specifically, very little research has addressed the question of the role of intellectual property protection towards knowledge assets which can freely be accessed, which are sometimes considered as public goods (Chou \& Passerini, 2009). Acs (2002) defined public goods as goods that are non-exclusive nor non-rival in their usage. They are non-rival in the sense that knowledge can be consumed without depleting it or becoming rivals, i.e. the idea or knowledge 
that a person has does not block others from having the same idea or knowledge (Suber, 2009). Copyright law recognized that knowledge is public goods since it only protects the expression of ideas, not the idea itself. Yet, privatizing expression of ideas, such as literary works, still impedes knowledge sharing.

The use of knowledge assets by informal education services has been very much understudied especially in the realm of religious studies. It is questionable whether there should be more measures of protection for these education-related products related to religious studies or more dissemination should be encouraged in the name of spreading religion. To this extent, Gilchrist \& Fitzgerald (2015) viewed that the aspect of intellectual property from the Islamic legal perspective is not much discussed in English literature although they acknowledged that it is one of the significant legal systems that needs to be addressed.

\section{For-profit and Non-profit Organizational Culture}

In discussing religious teaching, it is important to understand the difference between for-profit and non-profit organizational culture. Organizational culture may be discerned by espoused values which are conscious strategies, goals and philosophies (Schein, 1988). Culture may refer to basic assumptions, discovered by a given group that has worked well enough to be considered valid, and therefore, taught as the correct way to perceive, think or feel (Schein, 1988).

Studies have comparatively looked at the aspects of the culture of profit, non-profit or hybrid organizations and how they differ from each other. Billis (2010), for instance, revealed that private-sector organizations tend to maximize financial returns with ownership and a revenue model based on sales and fees, whereas non-profit sector organizations are more determined by their social goals, with a revenue model based on membership fees, donations and legacies. There is also a hybrid form of organization that acquires cross-sectorial beliefs and practices of both profit and non-profit organizational culture. A hybrid organization has both a social impact purpose and a drive for financial sustainability (Marchant, 2017). Some studies viewed that hybrid organizations had greater potential for sustainability issues especially in resource-constrained environments (Marchant, 2017). 


\section{Intellectual Property Protection in Islam}

Most studies on intellectual property protection in an Islamic legal perspective have only focused on whether Shari'a or Islamic laws recognize intellectual property protection of private ownership. These observations on the Islamic law perspectives relating to intellectual property may be seen in several studies. Some scholars argued that intellectual property rights protection are part of Shari'a, which do not conflict with the western principles of protection, as Islam protects individual ownership (Khan, Lone, \& Fayaz, 2017). A different view found that there are some tensions between the Western and the Islamic views on intellectual property pertaining to the role of economics within the Islamic law and society (Beltrametti, 2010). According to Beltrametti (2010), the Sharî'a based system is flexible and adaptable, thereby supporting intellectual property rights. Similarly, Azmi (1995) outlined various tensions between intellectual property law and Islamic law, ranging from the limits of ownership, abuse of rights, rules against restrictive trade practices, rules against unconscionable bargaining power, right for education and etc. (Azmi, 1995).

Elmahjub's (2014) analysis interestingly revealed that Islamic Shari'a acknowledges the intellectual property protection to private works based on the theory of fairness, utilitarianism and personality which is consistent with the Western literature but Shari'a further considers the effects intellectual property has on the society at large. The Shari' a principles take into account third parties' interests against the intellectual property owners' interest (Elmahjub, 2014). Here, further consideration, namely the principles of stewardship (khilafa) by which knowledge ownership belongs to Allah and humankind are merely trustees; non-concentration of wealth, abuse of rights and the encouragement for the dissemination of knowledge are embedded in the Islamic intellectual property system framework (Elmahjub, 2014). This approach may contribute to reduce the concentration of private power to expand the public domain, empower users of intellectual property products and contribute to greater openness and distribution of cultural and knowledge resources (Elmahjub, 2014). Shari'a promotes openness and non-concentration of knowledge resources, recognizes the role of the public domain, conceptualizes users' rights to access and reuse culture and knowledge; considers 
alternative modalities of knowledge production and promotes the dissemination of knowledge, and adopts access to knowledge initiatives and policies' (Elmahjub, 2015).

Although much past literature has observed that intellectual property is recognized in Shari'a law, albeit subject to certain conditions, few writers have been able to draw on any systematic research into how intellectual property rights protection applies to Islamic products and services related to knowledge and information. Little research has determined whether producers of Islamic products and services actually rely on intellectual property protection. The nature of intellectual property protection in the realm of informal religious education thus remains unclear.

\section{Intellectual Property in Religious Works}

All original literary works including the translation of the Bible or the Quran, in default, are subject to copyright law, as stipulated in Article 2(3) of the Berne Convention or TRIPs Agreement. Studies recognized the dilemma of withholding religious works upon payment of royalties or license since the Quran and the Bible are considered as God's word, and thus should not be owned as private intellectual property (Syn, 2001). Some viewed that copyright law protects translation from being tampered with as well as helps towards generating profits which pay for translation, printing and subsidizing religious works to others (Syn, 2001). Syn (2001) signifies that the church has a reciprocal duty to fairly remunerate those who put in the time, effort and labour to spread the gospel; that there is lawful right to sustenance in the scripture but those who forgo their right for the cause would be much better.

From the Islamic perspective, Islamic religiosity and materialism are negatively correlated (Ilter, Bayraktaroglu, \& Ipek, 2017). Children were normally sent to study the Quran from teachers who are traditionally not paid, but receive services and gifts, especially when the child completes the Quranic sequence (Gade, 1999). Islam regards that everything in this world belongs to God. God created property as well as man's effort for people to utilize. "It is He who created for you all that exists on earth" [al-Baqarah:29]; "He put at your disposal that which is in the heavens and that which is in the 
earth, all from Him" [al-Jathiyah:13]. In addition, Islam considers work as a way to improve oneself and the whole society; a religious duty and thus should be accomplished to the best of an individual's knowledge. Islamic work ethics stress the concept of halal and haram based on Islamic Shari'a; they also stress the importance of intentions and results (Mohammad \& Quoquab, 2016). Pursuing economic commodity without caring for the society should be commensurate with capitalism practices that concentrate on the production of wealth more than the distribution of wealth, which is against Islamic values.

Studying the role of intellectual property in religious works, thus requires careful analysis of the logic of copyright law in religious principles that seek to preserve its authenticity, and to disseminate freely (Ventimiglia, 2019). Public sermons and missionary activities are all designed to disseminate the word of God but may potentially be barred by monetary barriers or access to religious texts. In determining ownership of sacred and prophetic texts, it was shown that religion and law are fundamentally entangled and leading to complex litigation (Ventimiglia, 2019).

\section{METHODOLOGY}

The study presented here is one of the first investigations to explore the extent of intellectual property protection application on Islamic products and services, particularly related to informal education or teaching. Intellectual property protection here refers to the protection available in several Malaysian statutes, namely Copyright Act 1987 which protects literary, musical or artistic works, sound recordings, broadcasts and films for as long as 50 years; Patents Act 1983 which protects new inventions for as long as 20 years from the date of filing the application, Trademarks Act 1976 which prohibits persons from using registered trademarks and services without authorisation for as long as 10 years; and Industrial Designs Act 1996, which protects industrial designs like that of a personal property capable of transmission and protected for an initial period of 5 years and may be extended to the total protection period of 15 years. This study specifically focussed on the Quranic teaching and learning which is widely offered by various private business entities in Malaysia. 
An investigation on the Quranic teaching and learning was focused on since it is a common subject of learning by Muslims around the world, albeit formally, or informally. There are four steps in teaching and learning the Quran, namely reciting, understanding, memorizing and practicing the Quran (Ramli, Engkizar, \& Hamzah, 2017). This research, focused only the first step which is teaching and learning the recitation of the Quran.

Malaysia was specifically chosen as a case study since it is a multiracial country (Muslims make up over $60 \%$ of its population) with Islam as its official religion (Ramli \& Awang, 2018) and thus may represent the views of Asian or Muslim countries regarding intellectual property protection on knowledge assets. This will add fresh contributions to the discussion on intellectual property and knowledge or education. Malaysia has always taken the initiative to ensure that its intellectual property laws are in conformity with international standards and is consistently looking for solutions and strategies to fulfill intellectual property needs to accommodate its thriving global economy.

Data for this study were collected using the qualitative research approach, where it first looked into the general overviews collected through document analysis gathered from reports, brochures, journal articles, newspapers, the Internet, websites and mass media focusing on the creativity and innovation in informal religious education. It then adopted a multiple case study approach comparing several companies that used their creativity and innovation in offering Quranic education. The practices of three enterprises were examined and compared, recognizing that actions pursued by each organization are in addition to the existing practices and regulatory environment. Primary data were collected by way of semi-structured interviews and questionnaires through emails and personal in-depth (formal and informal) as well as phone interviews with the managers, owners and people involved in the Quranic teaching and learning initiatives. This work will generate fresh insight into the debate on the role of intellectual property protection of creative and innovative works that benefit the community.

Throughout this paper, the term 'innovation' takes the definition provided by the Merriam Webster Dictionary, which defines it as 'the 
introduction of something new, such as a new idea, a new method or a new device'. Specifically, for the purpose of this research, innovation relates to new ideas, methods, devices or tools that are used for teaching and learning Quranic recitation or memorization. It could also refer to innovative products, services or processes. The phrase 'informal education' will be used in this study to describe the form of action or process of educating, teaching, tutoring or developing certain kinds of knowledge. Specifically, it refers to the informal teaching and learning of Quranic lessons provided by private parties which exclude teaching and learning in schools or public educational institutions. 'Businesses' refers to commercial or industrial enterprises that are engaged in activities or dealings that are of an economic nature.

This paper identified to what extent innovative and creative methods are used to teach religiosity, particularly relating to Quranic teaching and learning. It then examined the relationship of intellectual property regulation in informal religious education offered by business enterprises in Malaysia. Based on the finding, this paper discussed the ways in which protection of creative and innovative works are used together with fulfilling the needs of the public to access beneficial works.

\section{FINDINGS}

\section{Development of Innovative Methods in Quranic Teaching}

Early practice of Quranic teaching and learning in Malaysia was undertaken mainly by individual religious teachers as well as religious institutions such as rumah guru and pondok. In 1871, Quranic teaching was incorporated into the mainstream Malay schools after school hours in the afternoon until 1962 when Quranic teaching was made part of the school curriculum (Aderi, Noh, Hussein, Ghani, \& Suhid, 2013). Now, Quranic teaching is well established at the institutional level such as in the Muslim faith schools (madrasah), primary and secondary schools, mosques and community centres around Malaysia (Aderi et al., 2013). At the same time, Quran teaching is also offered by various commercial enterprises that often tender different and innovative ideas, methods and tools to study the Quran. 
From early 1980 s to 1995 , Malaysians mostly used the Qira'ati method of learning the Quran introduced by KH Dachlan Salim Zarkasy from Semarang Central Java Indonesia (Ramli et al., 2017). This method was then replaced by the Iqra' method created by al-Marhum Ustaz H. As'ad Humam which has now become the common way used to teach the Quran in schools (Ramli et al., 2017). The common method of teaching the Quran involves the teacher calling each individual student to recite the Quran, while the teacher listens and corrects him or her on the correct pronunciations or the rules of Tajwid (Aderi et al., 2013).

New innovation and interesting methods of Quranic teaching and learning have been developed to make it easier, and to attract students (Ariffin, Ahmad, \& Abd Razzak, 2013) as well as to help faster, easier and better Quranic learning. In Malaysia alone, various Quranic teaching services have been offered, advertised and marketed by commercial enterprises. Moving from the common methods of learning the Quran, namely Muqaddam, Iqra' and Qiraati, new methods and techniques such as Haraki, Al-Hira, AsySyaathir, Abata, Al-Barqy, Al-Matien, Al-Baghdadi, Cardobana, Asy-syafi'i, Al-Jabari and Jibril have proliferated. Moreover, new innovations were also created to help those with special needs to learn the Quran. For instance, the Fakih innovative methodology was specifically designed to help people with hearing problems to read the Quran (Mohd Daud, Jomhari, \& Abdull Zubi, 2012).

New methods of reading, reciting and memorizing the Quran were widespread and largely introduced. Some utilized new methods or recitations, tools, systematic movements or actions, and apps or software to teach and learn the Quran more effectively. Various marketing tools were used to introduce the new innovative methods to society, such as via advertisements in the media, television, websites, banners and so on. These developments show that different innovative methods and ways of teaching and learning the Quran have been introduced to the Malaysian society.

For instance, the Al Baghdadi Group of Companies introduced a new innovative method to learn the Quran by utilizing new tools. Al Baghdadi became the finalist in the National Innovation Conference \& Exhibition (NICE) Award in 2017. A look at Al Baghdadi centre 
shows that this Quranic Learning Centre utilizes a new method of learning and teaching the Al-Quran which is systematic and innovative with the tapping technique (Teknik Ketukan) introduced by Ustaz Jalaluddin bin Haji Hassanuddin. The Baghdadi Quranic learning method has showcased a unique and innovative method of learning the Quran. It has applied several intellectual property protections on its assets. It has a registered trademark on its branding, a patent on its tools or alat ketuk used in teaching the Quran and a copyright on its books, CDs and modules used when teaching the Quran. The Al-Baghdadi Quranic Learning Centre which is recognized by The Malaysia Book of Records, is so far the largest Qur'anic-learning centre with approximately 1,168 branches nationwide and several branches abroad including Indonesia, Brunei and New Zealand (Al-Baghdadi 2017).

\section{Relationship of Intellectual Property Protection in Informal Religious Education}

Interviews with all the respondents who were involved in the Quranic teaching and learning initiatives showed that there is sufficient awareness or understanding of intellectual property. The respondents obtained their knowledge of intellectual property from colleagues as well as from workshops or training conducted by administrators. The respondents understood the licensing agreement processes and costs related to the administration of intellectual property. This clearly shows that intellectual property protection is somewhat related to informal religious education, particularly the Quran.

Respondents were asked to indicate whether intellectual property protection is important in their quest for spreading Quranic teaching. All suggested that intellectual property protection is important in their effort to teach the Quran. A common view amongst the interviewees was that users should acknowledge that the innovative methods were based on the creator's effort, investment and hard work despite the fact that the Holy Quran is from Allah. The new method or innovation used by creators to teach the Quran normally incur increased costs of research and development, marketing investment and competition from competitors. Thus, it is viewed that intellectual property should be recognized and supported in order for the new Quranic teaching method to be further disseminated and used. 
Owners and managers of Quranic teaching enterprises viewed that the licensing system under intellectual property enables them to monitor those who use their innovative method for quality control purposes so that it may gain more trust from the customers. To ensure the quality of their brand name, it is important for the administration to provide support, monitoring, and development workshops with certain fees attached. Intellectual property is also regarded as a new business income for the company which can be used to secure financial rewards that uphold the status and provide a stable reasonable income which can create a pool of professional Quranic instructors.

Nevertheless, the respondents' hold different views as to the role of intellectual property protection in the informal education-related businesses. Stronger views relate intellectual property registration as the means of providing their company with some form of legal recognition of their innovative product. Some respondents advertise their achievement of intellectual property award in their websites and other means of advertising to attract more customer' faith and trust in their company's services. Some respondents however, do not feel that intellectual property protection serves as a tool to encourage them to create more innovations since their main aim is to spread the teaching of the Quran that is highly ordained by God. One surprising finding was that the element of trust is more associated with the sharing of the creative or innovative method of teaching the Quran, rather than using legal measures to control or protect its creation. Hence, only some respondents, in isolated cases, have actually pursued legal actions on those who have violated their intellectual property rights. Together, these results provide important insights into the discussion of the role of intellectual property protection, where it only serves as a minimal encouragement mechanism when distributing religious knowledge.

\section{DISCUSSIONS}

\section{Quranic Teaching in Malaysia}

The development of various innovative methods of teaching the Quran reflects the current development of informal education or 
lifelong learning experience. In Malaysia, Quranic teaching is offered in primary schools and continued as lifelong learning. The growing phenomena of Quranic teaching is mostly "because of the Malaysian government's aggressive policy of Islamizing society beginning from the 1970s" (Grine \& Saeed, 2017). Such Muslim centric content emerged in the Malaysian culture as a consequence of Islamic globalization and the emergence of Muslim education culture in the Middle East, Europe as well as neighbouring Indonesia. Muslims, young and old feel obliged to recite and learn the Quran.

Education has surged to a new level due to the sheer number of new interesting methods and innovations in the techniques of teaching and learning. More and more innovative and creative tools and methods have been developed to attract students' attention to learning. The same has also been true for informal religious education, particularly in the teaching and learning of the Quran in Malaysia. Commercial or industrial enterprises are now engaged in activities involving religious products and services that are economic in nature. This is in addition to the profound impact that Internet resources have on the field. Such development is consistent with views that proper training and courses related to the Quran should be increased for a more effective way to learn the Quran (Noh, Tamuri, Razak, \& Suhid, 2014).

Essentially, these new innovative products and the business of Quranic teaching may be considered as both an act of worship and dawah made in pursuit of divine satisfaction as well as an act of gaining commercial advantage. Despite the belief in Islam that everything comes from God, including knowledge, and the Quran as the Divine speech, there is the general understanding that the Quranic teaching strategy or methods may be protected and marketed as privately owned in a business environment. Business enterprises viewed that it is pertinent that Quranic teaching methods be protected by intellectual property rather than believing that the method should be used freely to spread religious obligations. While teaching the Quran is essentially considered as a religious obligation, it also fills as an economic tool for business purposes which will, in turn, enhance the status and professionalism of Quranic teachers in Malaysia. 


\section{Relationship of Intellectual Property to Informal Religious Services}

The finding shows that intellectual property protection is used as a strategic tool to enhance informal religious education. Moreover, it reveals that owners' of creative works are aware of the importance of intellectual property but do not really think that intellectual property is crucial for protecting their businesses. This is consistent with Shari'a teachings that recognizes ownership over ideas and expressions that result from the productive efforts of creators. and enjoins people to respect the fruits of labour that promotes welfare in the society's progress and development (Elmahjub, 2014). Islamic belief and culture put a strong emphasis on familiar community values and strong protection of public interest (Yu, 2012). This is in line with the Western justification of intellectual property law based on the utilitarian theory. Moreover, although Islam regards that all things belong to Allah, it does not deny private ownership of asset as inherent in human nature (Elmahjub, 2014) and this is also reflected in the personality theory articulated by Fisher (Fisher, 2001). Muslim scholars have also viewed that it is permissible to charge for lessons or services or to learn the Quran and this is considered not to be inconsistent with God's ownership of property.

Prior studies have noted the importance of intellectual property protection in encouraging creativity and innovation. The results of this study, however, showed that intellectual property protection is not used to encourage creativity and innovation, but only as a safeguard to a new innovation that is already in place.

The interesting finding of this study is that the element of "trust" is more relied on when sharing a creative method of teaching the Quran with others, rather than relying on intellectual property to protect creativity and innovation. This may possibly be explained by virtue of the Muslim culture, where teaching and learning the Quran is an obligation for every Muslim (Noh et al., 2014). For Muslims, the Holy Quran is the fountain head of the entire learning and consistently remains as the center of the Muslim's source of belief and reference. It is a responsibility for a Muslim to be taught Quranic recitation, memorization, interpretation, understanding and appreciation from a young age till the end of time as this Holy Book 
is a guidance on how Muslims should lead their lives. The finding on trust also supports previous studies signifying that the trust, selfefficacy, altruism, self-motivation and enjoyment are significant factors influencing knowledge sharing in small medium enterprises (Ibrahim \& Heng, 2017).

This finding may also be explained by the fact that seeking and knowledge sharing are highlighted in not only Islam, but also in Christianity, Buddhism and the ancient Indian education system (Anand \& Walsh, 2016).

Various teachings of the Prophet (pbuh) similarly enjoin the importance of seeking and sharing knowledge with others. It was narrated that Abu Hurairah said: The Messenger of Allah said...

"Whoever follows a path in pursuit of knowledge, Allah will make easy for him a path to paradise. No people gather in one of the houses of Allah reciting the Book of Allah and teaching it to one another, but the angels will surround them, tranquility will descend upon them, mercy will envelop them, and Allah will mention them to those who are with Him".

In another Hadith, Abu Hurairah reported that the Messenger of Allah (pbuh) said, "Allah makes the way to Jannah easy for him who treads the path in search of knowledge." Prophet Muhammad (pbuh) also said, He who is asked about knowledge and conceals it, will be bridled with fire on the Day of Resurrection". These teachings of Prophet Muhammad (pbuh) shows that the act of hoarding knowledge is sin and the culture of sharing should be adopted by everyone if they want to meet a path of mercy and tranquility in Islam (Dindang, Mamarinta, \& Mababaya, 2005).

Similarly, Christianity also enjoins that knowledge be shared and passed to others. "My people are destroyed for lack of knowledge. Because you have rejected knowledge, I also will reject you from being my priest. Since you have forgotten the law of your God, I also will forget your children" (Hosea 4:6). Thus, knowledge implies the responsibility that it needs to be shared, whether freely or with fees. 
It is encouraging to compare this finding with another study which found that making books freely available online, including religious books, is a financially feasible move as it does not bring a negative effect on sales but creates broader access for users (Hilton, 2010). Moreover, there is a social requirement for information and knowledge to be disseminated as widely as possible for public benefit, particularly those involving spiritual or religious education.

Religion plays a very important factor in influencing people's attitudes, values and behaviour. The concept of religiosity (belief in God and commitment to act according to God's principles) (Zarif, Mohamad, \& Bakar, 2014) could highly determine the values, behaviour and human convictions (Vitell \& Paolillo, 2003). Although more Muslims are keen to take part in global commercial culture, many still remain faithful to their Islamic values in their everyday practice. This is primarily true for countries in the Middle East and some Asian countries like Indonesia, Malaysia and Pakistan. Moreover, Islam is one of the world's largest belief system and, thus its principles are relevant in regulating the legal system for society. The Islamic system is thus somewhat different from the concept of materialism, which is primarily emphasizing the importance of material possessions that provides a good life, satisfaction and progress (Ilter et al., 2017). Based on the circumstances and subject matter of the case, this argument supports the view that the intellectual property reward regime has to be flexible and based rather on contractual arrangements than on rigid imperative legal norms (Mets \& Kelli, 2014).

\section{CONCLUSION}

This study set out to determine the role of intellectual property protection in informal religious education, particularly using Quranic teaching as a case study. This study has raised important questions about the nature of intellectual property protection in certain creative and innovative endeavours. This study has identified that the value of intellectual property is acknowledged and seen as a valuable business asset. Nevertheless, intellectual 
property protection serves a minimal role in encouraging innovation or the spread of Quranic teaching. These results add to the rapidly expanding field of intellectual property in Industrial Revolution 4.0 where creativity and innovation play crucial roles. This new understanding should help to improve the predictions of the impact of intellectual property protection towards innovation and creativity. The findings suggest that innovation and creativity would still be produced with or without intellectual property protection. The findings point to the need for better consolidation of innovative and creative religious works which can be a point to be taken for future research. Intellectual property protection should be perceived to be a tool for achieving the overall development and social welfare of the society, not only for private gain. Islamic principles such as stewardship, dissemination of knowledge and distributive justice can contribute towards ensuring that intellectual property takes into account fundamental human needs. Continued efforts are needed to make innovative beneficial works available for people's use. For intellectual property to be considered as important and taken seriously, it must take into consideration, the consistency of the beliefs and sentiments of the people that it serves to protect.

\section{ACKNOWLEDGEMENT}

This research was conducted under the support of Geran Penjanaan Penyelidikan Universiti Utara Malaysia (Kod S/O 13944). This paper was also presented in the International Conference on International Studies (ICIS) 2018 in December in Medan, Indonesia.

\section{REFERENCES}

Acs, Z. J. (2002). Innovation and the growth of cities. Cheltenham: Edward Elgar Publishing Ltd.

Aderi, M., Noh, C., Hussein, A., Ghani, O., \& Suhid, A. (2013). The study of Quranic teaching and learning: A review in Malaysia and the United Kingdom. Middle-East Journal of Scientific Research, 15(10), 1338-1344. https://doi.org/10.5829/idosi. mejsr.2013.15.10.11509 
Anand, A., \& Walsh, I. (2016). Should knowledge be shared generously? Tracing insights from past to present and describing a model. Journal of Knowledge Management, 20(4), 713-730. Retrieved from https://doi.org/10.1108/ JKM-10-2015-0401

Ariffin, S., Ahmad, K., \& Abd Razzak, M. (2013). Effective techniques of memorizing the Quran: A study at Madrasah tahfiz Al-quran, Terengganu, Malaysia. Middle-East Journal of Scientific Research, 13(1), 45-48. https://doi.org/10.5829/ idosi.mejsr.2013.13.1.1762

Azmi, I. M. (1995). Intellectual property laws and Islam in Malaysia. Queen Mary University of London. Retrieved from http:// qmro.qmul.ac.uk/jspui/handle/123456789/1418

Beltrametti, S. (2010). The legality of intellectual property rights under Islamic Law. In T. Mach (Ed.), The Prague Yearbook of Comparative Law 2009 (pp. 55-94). Prague: Anglo-American University. https://doi.org/9788025465516

Billis, D. (2010). Hybrid organizations and the third sector. Challenges for practice, theory and policy. London: Palgrave MacMillan.

Burkitt, D. (2001). Copyrighting culture - the history and cultural specificity of the Western model of copyright. Intellectual Property Quarterly, 2, 146-186.

Carayannis, E. G., \& Alexander, M. J. (1998). The wealth of knowledge: Converting intellectual property to intellectual capital in co-opetitive research and technology management settings. International Journal of Technology Management, 4(3). https://doi.org/10.1504/IJTM.1999.002769

Chou, P. Ben, \& Passerini, K. (2009). Intellectual property rights and knowledge sharing across countries. Journal of Knowledge Management Library Hi Tech Iss Journal of Intellectual Capital, 13(5), 331-344. Retrieved from https:// doi.org/10.1108/13673270910988141//

Dindang, N., Mamarinta, M., \& Mababaya, O. (2005). Religious curricular offerings in the Muslim world: Challenges and prospects in the light of strategic planning, social networking, modern technological advancement and globalization of Islamic knowledge. In International Seminar on Religious Curricular in the Muslim World: Challenges and Prospects (pp. 1-27). Kuala Lumpur: International Islamic University 
Malaysia. Retrieved from http://citeseerx.ist.psu.edu/ viewdoc/download?doi=10.1.1.543.9775\&rep=rep1\&type $=$ p df

Elmahjub, E. (2015). An Islamic perspective on the theories of intellectual property. In Copyright Perspectives: Past Present and Prospect (pp. 51-84). Cham: Springer International Publishing. https://doi.org/10.1007/978-3-319-15913-3_5

Elmahjub, E. M. (2014). Protection of intellectual property in Islamic Shari' $a$ and the development of the Libyan intellectual property system. Queensland University of Technology. Retrieved from https://eprints.qut.edu.au/76106/

Elmahjub, E. M. (2015). Copyright perspectives: Past, present and prospect. (B. Fitzgerald \& J. Gilchrist, Eds.). Switzerland: Springer International Publishing. https://doi. org/10.1007/978-3-319-15913-3

Fisher, W. (2001). Theories of intellectual property. In New essays in the legal and political theory of property (pp. 168-199). Retrieved from http://xa.yimg.com/kq/ groups/27799060/1918334176/name/iptheory.pdf

Gade, A. M. (1999). An envy of goodness: Learning to recite the Qur'an in modern Indonesia. The University of Chicago.

Grine, F., \& Saeed, M. (2017). Is Hijab a fashion statement? A study of Malaysian Muslim women. Journal of Islamic Marketing, 8(2), 00. https://doi.org/10.1108/JIMA-04-2015-0029

Guanhong, T. (2004). A comparative study of copyright and the public interest in the United Kingdom and China. SCRIPTEd, 1(2), 272-300. https://doi.org/10.2966/scrip.010204.272

Hilton, J. I. (2010). "Freely ye have received, freely give" (Matthew 10:8): How giving away religious digital books influences the print sales of those books. Brigham Young University. Retrieved from https://scholarsarchive.byu.edu/etd/2022/

Hilty, R. M. (2005). Five lessons about Copyright in the information society: Reaction of the scientific community to overprotection and what policy makers should learn. Journal of the Copyright Society of the U.S.A., 53(1), 103.

Ibrahim, S., \& Heng, L. H. (2017). The effect of individual motivational factors towards knowledge sharing at small and medium enterprises. International Journal of Knowledge Management Studies, 8(3-4), 210-231. https://doi. org/10.1504/IJKMS.2017.087068 
Ilter, B., Bayraktaroglu, G., \& Ipek, I. (2017). Impact of Islamic religiosity on materialistic values in Turkey. Journal of Islamic Marketing, 8(4), 533-557. https://doi.org/10.1108/ JIMA-12-2015-0092

Khan, J. I., Lone, N. A., \& Fayaz, A. S. (2017). Intellectual property rights in Islam: A perspective. International Journal of Research in Social Sciences, 3(1), 153-162. Retrieved from https://www.academia.edu/4535433/Intellectual_Property_ Rights_in_Islam_A_Perspective?auto=download

Marchant, E. R. (2017). Organizational cultural hybrids: Non-profit and for-profit cultural influences in the Kenyan technology sector. In B. Ndemo \& T. Weiss (Eds.), Digital Kenya: An entrepreneurial revolution in the making (pp.303-336). United Kingdom: Palgrave MacMillan. https://doi.org/10.1057/9781-137-57878-5

Mets, T., \& Kelli, A. (2014). The impact of intellectual property reward regime on the competitiveness of innovative SMEs. Economics and Business, 24(24), 99. https://doi.org/10.7250/ eb.2013.012

Mohammad, J., \& Quoquab, F. (2016). Furthering the thought on Islamic work ethic: How does it differ? Journal of Islamic Marketing Article, 7(3), 1-19. https://doi. org/10.1108/17590831311306336

Mohd Daud, A., Jomhari, N., \& Abdull Zubi, N. I. (2012). FAKIH: A method to teach deaf people "Reading" Quran. In The 2nd Annual International Qur'anic Conference. Kuala Lumpur: University of Malaya. Retrieved from http://eprints.um.edu. my/13977/

Noh, M. A. C., Tamuri, A. H., Razak, K. A., \& Suhid, A. (2014). The study of Quranic teaching and learning: United Kingdom experience. Mediterranean Journal of Social Sciences, 5(16), 313-317. https://doi.org/10.5901/mjss.2014.v5n16p313

O'Donoghue, N., \& Croasdell, D. T. (2009). Protecting knowledge assets in multinational enterprises: A comparative case approach. VINE, 39(4), 298-318. Retrieved from https://doi. org $/ 10.1108 / 03055720911013616$

Ramli, A. F., \& Awang, J. (2018). A history of interfaith dialogue in Malaysia. Jurnal Hadhari, 10(2), 169-190.

Ramli, A. J., Engkizar, M., \& Hamzah, M. I. (2017). Implementation and development of Qur'an learning method in Malaysia and 
Indonesia: An analysis. Khalifa Journal of Islamic Education, 1(1). Retrieved from https://www.academia.edu/35756017/ Implementation_and_Development_of_Quran_Learning Method_in_Malaysia_and_Indonesia_An_Analysis

Schein, E. H.(1988). Organizational culture. American Psychological Association, 45(2), 109.

Shanmugaiah, K. (2012). The impact of TRIPs agreement on access to medicines in developing countries: Legal challenges faced by the pharmaceutical industry particularly in India. UUM Journal of Legal Studies, 3. Retrieved from http://www. uumjls.uum.edu.my/images/2012-PastIssues/3-2012.pdf

Suber, P. (2009). Knowledge as a public good. SPARC Open Access Newsletter, (139). Retrieved from https://dash. harvard.edu/bitstream/handle/1/4391171/suber_public good. html? sequence $=1$

Sukarmijan, S.-S., \& Sapong, O. D. V. (2014). The importance of intellectual property for SMEs; Challenges and moving forward. UMK Procedia, 1, 74-81. https://doi.org/10.1016/J. UMKPRO.2014.07.010

Syn, R. (2001). Enforcement of copyright in the Bible and religious works. Regent University Law Review, 14(1).

Ventimiglia, A. (2019). Copyrighting God: Ownership of the sacred in American religion. Cambridge: Cambridge University Press.

Vitell, S. J., \& Paolillo, J. G. P. (2003). Consumer ethics: The role of religiosity. Journal of Business Ethics, 46(2), 151-162. https://doi.org/10.1023/A:1025081005272

Wipo. (n.d.). What is intellectual property? Retrieved from http:// www.wipo.int/edocs/pubdocs/en/intproperty/450/wipo pub_450.pdf

Yu, P. K. (2012). Intellectual property and Asian values. Marquette Intellectual Property Law Review, 16, 329-399. Retrieved from http://scholarship.law.marquette.edu/iplrhttp://scholarship.law. marquette.edu/iplr/vol16/iss2/7

Zarif, M. M. M., Mohamad, N., \& Bakar, B. A. (2014). Assessing Quranic reading proficiency in the j-QAF programme. International Education Studies, 7(6). https://doi.org/10.5539/ ies.v7n6p1 